\title{
2 Dietary factors and the risk of developing insulin dependent diabetes in childhood
}

\author{
Gisela G|Dahlquist, Leif Q Blom, Lars-Åke Persson, Anita I MLSandström, Stig G I Wall
}

\begin{abstract}
Objective-To study different nutrients and food additives as risk factors for insulin dependent diabetes mellitus in childhood.

Design-Prospective case-control study. Parents of the children being studied were asked to fill in a questionnaire regarding the children's frequency of consumption of various foods. Parents of children with diabetes were asked about the period before onset of the disease.
\end{abstract}

Setting-Population based study throughout Sweden.

Subjects-339 Children aged 0-14 who had recently developed insulin dependent diabetes mellitus and 528 control children matched for age, sex, and county of residence who were traced through the official Swedish population register.

Main outcome measures-Foods were classified according to their content of protein, fat, carbohydrates, monosaccharides or disaccharides, nitrosamines, nitrates or nitrites, vitamin $\mathrm{C}$, and fibres. The frequency of intake was categorised as high, medium, and low and the relative risk for developing insulin dependent diabetes was estimated for the three frequencies of intake and calculated as odds ratios.

Results-Significant linear trends for dose response in odds ratios by frequency of intake were shown for solid foods containing high amounts of protein (odds ratio for low frequency of intake 1.0 ; medium 2.3; and high 5.5 ), and nitrosamines (1.0; $1 \cdot 7 ; 2 \cdot 6)$ and significant but non-linear trends were found for carbohydrates $(1 \cdot 0 ; 1 \cdot 3 ; 4.4)$ and nitrates or nitrites $(1.0 ; 0.8 ; 2.4)$. The significant trends were not affected when the results were standardised for possible confounders. No significant increases in odds ratios were found for protein, monosaccharides and disaccharides, vitamin C, and fibres.

Conclusion-Nutrients and food additives such as protein, carbohydrate, and nitrosamine compounds may influence the risk of developing insulin dependent diabetes in childhood and significant trends in odds ratios indicate a causal relation.

Kepartment of Pediatrics Karolinska Institute, Sachs' Children's Hospital, S-116 69 Stockholm] Gisela G Dahlquist, MD, assistant professor

Leif G Blom, MD, registrar

Department of

Epidemiology and Health

Care Research, University of Umeå, Umeå, Sweden. Lars-Ảke Persson, MD, registrar

Anita I M Sandström, BA, statistician

Stig G I Wall, PHD, professor

Correspondence and requests for reprints to: Dr Dahlquist.

Br.Mcd 7 1990:300:1302-6 ally reducing some protein components in the rats' diet the incidence of diabetes was decreased." Another study suggested that nitrosamines from smoked mutton eaten by pregnant women, and thus passed on to their fetuses, increased the incidence of type I diabetes in their children. ${ }^{\text {" The toxicity of nitrosamine }}$ compounds to the $\mathrm{B}$ cell has also been confirmed in experimental studies in mice ${ }^{1 t}$ and Chinese hamsters. " We have investigated whether there were any differences in the food habits of diabetic children during the period before onset of diabetes compared with control children matched for age, sex, and county of residence.

\section{Subjects and methods}

The study was approved by the ethics committee at the Karolinska Institute and the Swedish data inspection board.

Under the Swedish system of health care all children aged 0-14 with suspected diabetes are referred to a paediatric department. Basic data on incident cases of type I diabetes are reported to the Swedish Childhood Diabetes Registry, as previously described. ${ }^{16}$ The register has been evaluated by both an internal and an external source of validation and estimated to include over $99 \%$ of the cases occurring. ' We conducted a casecontrol study from 1 September 1985 to 31 August 1986 covering all cases of diabetes reported to the registry in children aged $0-14$. For each diabetic child two controls matched for age, sex, and county of residence were traced through the official Swedish population register. A questionnaire on food habits was sent to the parents of all children in the study, but they were not told that we were studying diabetes. The method for collecting the data has recently been presented in detail."

The parents of both diabetic and control children were asked if they had changed their food habits during the three months before completing the questionnaire and, if so, to describe their food habits before this recent change. The section on food in the questionnaire was designed to assess frequency of consumption and was similar to that used by Holm et al. ${ }^{17}$ The food frequency form has been evaluated and compared with seven day food records; no systematic differences were found in the pattern of answering between diabetic children and healthy controls matched for age. "s The frequency of intake of different foods was estimated by recording the weekly intake of 36 foods individually; the questionnaire had five different responses: a frequency of 0 , one, four, seven, 15, or 28 times a week. (Porridge and stewed vegetables were excluded from the analysis because nobody had recorded eating them.) Consumption of milk and sour milk was combined as was consumption of fried and cooked eggs. The individual foods were classified into groups according to whether they contained nutrients of special interest concerning diabetes-for example, foods with a high content $(>10 \mathrm{~g} / 100 \mathrm{~g})$ of carbohydrates, protein, or fat according to data from the Swedish national food administration. ${ }^{10}$ Foods treated with nitrate or nitrite as a preservative ${ }^{21}$ were also 


\begin{tabular}{|c|c|c|c|c|c|c|c|c|c|c|}
\hline & \multirow{2}{*}{$\begin{array}{l}\text { Carbohydrate } \\
(>10 \mathrm{~g} / 100 \mathrm{~g})\end{array}$} & \multirow{2}{*}{$\begin{array}{c}\text { Monosaccharide } \\
\text { or disaccharides } \\
(>10 \mathrm{~g} / 100 \mathrm{~g})\end{array}$} & \multirow{2}{*}{$\begin{array}{c}\text { Protein } \\
(>10 \mathrm{~g} / 100 \mathrm{~g})\end{array}$} & \multirow{2}{*}{$\begin{array}{c}\text { Fat } \\
(>10 \mathrm{~g} / 100 \mathrm{~g})\end{array}$} & \multirow{2}{*}{$\begin{array}{l}\text { Nitrate or } \\
\text { nitrite }\end{array}$} & \multirow[b]{2}{*}{ Nitrosamines $†$} & \multirow{2}{*}{$\begin{array}{c}\text { Vitamin C } \\
(>10 \mathrm{mg} / 100 \mathrm{~g})\end{array}$} & \multirow{2}{*}{$\begin{array}{c}\text { Fibres } \\
(>4 \mathrm{~g} / 100 \mathrm{~g})\end{array}$} & \multicolumn{2}{|c|}{$\begin{array}{l}\text { Mean No of times } \\
\text { food consumed each week }\end{array}$} \\
\hline & & & & & & & & & Diabetic & Control \\
\hline Fresh green & & & & & & & & & & \\
\hline vegetables $\ddagger$ & & & & & + & & + & & 3.9 & $3 \cdot 5$ \\
\hline Boiled vegetables & & & & & + & & + & + & $7 \cdot 3$ & $6 \cdot 6$ \\
\hline Fruits and berries & + & + & & & & & + & & $9 \cdot 1$ & $9 \cdot 0$ \\
\hline Boiled potatoes $\ddagger$ & + & & & & & & + & & $7 \cdot 5$ & $6 \cdot 7$ \\
\hline Fried potatoes $\ddagger$ & + & & & + & & & & & $1 \cdot 2$ & 0.5 \\
\hline $\begin{array}{l}\text { Root vegetables } \\
\text { (not potatoes) } \ddagger\end{array}$ & + & & & & + & & & & $3 \cdot 1$ & $2 \cdot 6$ \\
\hline Pasta and rice $\ddagger$ & + & & & & & & & & $2 \cdot 9$ & $2 \cdot 3$ \\
\hline Dark crisp bread $\neq$ & + & & & & & & & + & $12 \cdot 8$ & $13 \cdot 1$ \\
\hline White bread $\neq$ & + & & & & & & & & $7 \cdot 2$ & $4 \cdot 8$ \\
\hline Buns and biscuits & + & + & & t & & & & & $4 \cdot \overline{8}$ & $4 \cdot 0$ \\
\hline Sweets $\ddagger$ & + & + & & & & & & & $2 \cdot 7$ & $2 \cdot 2$ \\
\hline Cheese $\ddagger$ & & & + & + & + & & & & $8 \cdot 4$ & $7 \cdot 1$ \\
\hline Cream $\neq$ & & & & + & & & & & $1 \cdot 1$ & $0 \cdot 8$ \\
\hline Ice cream & t & + & & + & & & & & $3 \cdot 4$ & $2 \cdot 8$ \\
\hline Fruit juiceł & t & + & & & & & + & & $3 \cdot 5$ & $2 \cdot 7$ \\
\hline Lemonade $\ddagger$ & + & + & & & & & & & $5 \cdot 3$ & $3 \cdot 5$ \\
\hline Fish: & & & & & & & & & & \\
\hline Boiled $\neq$ & & & + & & & & & & $1 \cdot 1$ & 1.0 \\
\hline Fried & '. & & + & & & & & & $0 \cdot 8$ & $0 \cdot 6$ \\
\hline Smoked & & & + & & & + & & & 0.03 & $0 \cdot 02$ \\
\hline Caviar and herring $\neq$ & & & & & + & & & & $1 \cdot 2$ & 1.0 \\
\hline Meat: & & & & & & & & & & \\
\hline Minced $\neq$ & & & + & + & & & & & $2 \cdot 7$ & 1.9 \\
\hline Boiled & & & + & + & & . & & & $1 \cdot 7$ & $1 \cdot 3$ \\
\hline Fried $\ddagger$ & & & + & + & & & & & $2 \cdot 1$ & $1 \cdot 3$ \\
\hline Sausage $\ddagger$ & & & + & + & + & . & & & $2 \cdot 1$ & $1 \cdot 3$ \\
\hline Liver and pasteł & & & + & + & & . & & & $4 \cdot 0$ & $3 \cdot 6$ \\
\hline Bacon & & & + & t & + & + & & & $0 \cdot 44$ & $0 \cdot 26$ \\
\hline Smoked sausage $\ddagger$ & & & + & + & & + & & & $2 \cdot 2$ & $1 \cdot 1$ \\
\hline Liver and kidney & & & + & & & & & & $0 \cdot 3$ & $0 \cdot 3$ \\
\hline Egg & & & t & + & & & & & $2 \cdot 9$ & $2 \cdot 5$ \\
\hline Marmalade and jam & + & + & & & & & & & $4 \cdot 5$ & $3 \cdot 5$ \\
\hline Sweet soups & + & + & & & & & & & $1 \cdot 3$ & $1 \cdot 1$ \\
\hline Milk $\ddagger$ & & & & & & & & & $18 \cdot 2$ & $20 \cdot 1$ \\
\hline
\end{tabular}

^Meat products treated with nitrite solutions for preservation. ${ }^{\natural} \quad$ †Foods shown to contain measurable amounts of nitrosocompounds. ${ }^{21} \quad \neq$ Foods included in the discriminant analysis.

TABLE II-Accuracy of discriminant analysis based on diet for predicting whether children have diabetes

\begin{tabular}{lcccc}
\hline & No of & & \multicolumn{2}{c}{ No(\%) of children predicted to be } \\
\cline { 3 - 4 } & children & Diabetic & Non-diabetic \\
\hline Diabetic children & 339 & $237(70)$ & $102(30)$ \\
Control children & 528 & $126(24)$ & $402(76)$
\end{tabular}

of interest as these compounds may be changed to nitrosamines under special circumstances. ${ }^{21}$ Foods with a measurable content of nitrosamines were also classified,, 2 as were foods rich in vitamin $\mathrm{C}$ $(>10 \mathrm{mg} / 100 \mathrm{~g})$, which may have a protective role against the effect of nitrosamine compounds, and fibre, which affects the rate of absorption of foods from the gut. ${ }^{2+}$ The intake of milk was analysed separately as it is not only a beverage but an important source of energy in Sweden, being rich in protein, fat, and carbohydrate. The frequency of intake of different nutrients was then categorised according to the distribution of intake in all the children studied; low intake was classified as that $<25$ th centile of frequency of intake, medium intake as that in the 25 th to 75 th centile, and high intake as that $>75$ th centile.

Copies of the questionnaire are available from the authors.

\section{STATISTICS}

To avoid losing precision during the analysis the matching was disregarded because we had previously found that the ratios between the relative risk from matched and unmatched data for the important associations were close to one. ${ }^{25}$ The overall characteristics of frequency of consumption of foods and meal patterns for the two groups of children were evaluated by discriminant analysis. ${ }^{26}$ Odds ratios for the risk of developing diabetes and $95 \%$ confidence intervals were calculated according to the method described by Miettinen. ${ }^{27}$ To control for possible confounding, standardised odds ratios and $95 \%$ confidence intervals were calculated. A possible trend in dose response was analysed using the Mantel-Haenszel extension test, and $a \chi^{2}$ test was used to analyse the homogeneity in the trend between different degrees of consumption. The analyses were performed using the QUEST software developed for the Swedish Medical Research Council by L Gustafsson, University of Umeå, Sweden.

\section{Results}

Completed questionnaires were returned by the parents of $339(87 \%)$ children with diabetes and 528 $(67 \%)$ control children. There were no systematic differences between the children for whom a questionnaire was returned and those for whom one was not with regard to age, sex, and county of residence. Almost all the questionnaires were completed by the children's mothers, only $61(7 \%)$ being returned by fathers.

Table I shows the nutrient and additive contents of various foods and their weekly frequency of intake by the diabetic and control children. Discriminant analysis was used to select the "discriminating" variables, which are indicated in the table. These 21 foods were then used to predict whether the children were in the diabetic or control group (table II). The prediction was correct in $659(73 \cdot 7 \%)$ children.

Table III gives the crude odds ratios and 95\% confidence intervals for insulin dependent diabetes mellitus for different frequencies of intake of milk and foods high in nutrients or additives that may be associated with diabetes. Significant trends were noted for frcquency of intake of solid foods rich in protein, fat, carbohydrate, monosaccharides or disaccharides, and for foods containing nitrosamines and nitrates or nitrites. The trends were non-linear for carbohydrates and nitrates or nitrites. For milk alone a slight decrease in odds ratio was noted, whereas the combined effect of milk and milk products (cheese, cream, ice cream) had no effect on the odds ratio.

Most nutrients classified as rich in proteins are also 


\begin{tabular}{|c|c|c|c|c|c|c|}
\hline & \multicolumn{6}{|c|}{ Odds ratio ( $95 \%$ confidence interval) } \\
\hline & $\begin{array}{l}\text { Low } \\
(<25 \mathrm{~cm} \\
\text { centile })\end{array}$ & $\begin{array}{l}\text { Medium } \\
\text { (25th-75th } \\
\text { centile) }\end{array}$ & $\begin{array}{l}\text { High } \\
(>75 \text { th } \\
\text { centile })\end{array}$ & $\begin{array}{l}\text { Low } v \text { medium } \\
\text { and high }\end{array}$ & $\begin{array}{l}\mathrm{p} \text { Value for } \\
\text { trend in } \\
\text { odds ratio }\end{array}$ & $\begin{array}{c}p \text { Value for } \\
\text { departure from } \\
\text { linearity }\end{array}$ \\
\hline Protein & $1 \cdot 0$ & $2.34(1.58$ to 3.45$)$ & $5 \cdot 49(3.63$ to $8 \cdot 28)$ & $3.23(2.25$ to 4.62$)$ & $<0 \cdot 0001$ & 0.57 \\
\hline Fat & 1.0 & $1.96(1.34$ to 2.86$)$ & $4.93(3.26$ to 7.46$)$ & $2.69(1.89$ to 3.83$)$ & $<0.0001$ & $0 \cdot 20$ \\
\hline Carbohydrates & 1.0 & $1.33(0.91$ to 1.93$)$ & $4.35(2.89$ to 6.56$)$ & $2.03(1.43$ to 2.88$)$ & $<0 \cdot 0001$ & $<0.0001$ \\
\hline Monosaccharides or disaccharides & 1.0 & $1.44(1.00$ to 2.08$)$ & $2.90(1.95$ to 4.33$)$ & $1.87(1.33$ to 2.63$)$ & $<0.0001$ & 0.17 \\
\hline Nitrosamines & 1.0 & $1.73(1.23$ to 2.44$)$ & $2.56(1.83$ to 3.59$)$ & $2.11(1.59$ to 2.80$)$ & $<0.0001$ & $(0.72$ \\
\hline Nitrates or nitrites & $1 \cdot 0$ & $0.84(0.59$ to 1.19$)$ & $2.41(1.64$ to 3.54$)$ & $1.24(0.90$ to 1.71$)$ & $<0.0001$ & $<0.0001$ \\
\hline Fibre & 1.0 & $0.55(0.37$ to 0.81$)$ & $0.84(0.61$ to 1.16$)$ & $0.73(0.54$ to 0.99$)$ & 0.51 & 0.003 \\
\hline Vitamin C & $1 \cdot 0$ & $0.79(0.56$ to 1.13$)$ & $1.54(1.06$ to 2.23$)$ & $1.04(0.75$ to 1.42$)$ & 0.02 & $0 \cdot 002$ \\
\hline Milk & 1.0 & $0.54(0.38$ to 0.77$)$ & $0.67(0.47$ to 0.95$)$ & $0.60(0.45$ to 0.80$)$ & 0.01 & 0.02 \\
\hline Milk and milk products & 1.0 & $0.95(0.67$ to 1.34$)$ & $1.02(0.69$ to 1.51$)$ & $0.98(0.71$ to 1.34$)$ & 0.88 & 0.66 \\
\hline
\end{tabular}

rich in fat (see table I). A separate analysis was therefore performed for protein as a risk factor when standardised for intake of fat. The Mantel-Haenszel risk estimates for a medium intake of protein were $1.71(\mathrm{p}=0.02)$ and for a high intake $3.03(\dot{\mathrm{p}}<0.001)$, and the Mantel-Haenszel extension tests was still highly significant $(\mathrm{p}<0.0001)$. When a similar analysis was performed for fat as a risk factor when standardised for frequency of intake of protein the MantelHaenszel risk estimates were $1.18(p=0.46)$ for medium intake of fat and $1.62(p=0.22)$ for high intake of fat. Thus, protein rather than fat seemed to be the risk factor for insulin dependent diabetes when children had a high frequency of intake of meat products.

Foods rich in nitrosamines are also rich in protein (see table I). The odds ratios for nitrosamines were therefore stratified for different levels of protein intake (table IV). Nitrosamines remained significant risk

TABLE IV-Odds ratios for insulin dependent diabetes for different frequencies of intake of food containing nitrosamine compounds stratified for different frequencies of protein intake

\begin{tabular}{|c|c|c|}
\hline Protein intake & Nitrosamine intake & $\begin{array}{c}\text { Odds ratio } \\
\text { (95\% confidence } \\
\text { interval) }\end{array}$ \\
\hline Low & $\begin{array}{l}\text { Low } \\
\text { Medium } \\
\text { High }\end{array}$ & $\begin{array}{l}1 \cdot 00 \\
1 \cdot 36(0 \cdot 59 \text { to } 3 \cdot 18)\end{array}$ \\
\hline Medium & $\begin{array}{l}\text { Low } \\
\text { Medium } \\
\text { High }\end{array}$ & $\begin{array}{l}1.00 \\
1.27(0.79 \text { to } 2 \cdot 04) \\
1.41(0.82 \text { to } 2.42)\end{array}$ \\
\hline High & $\begin{array}{l}\text { Low } \\
\text { Medium } \\
\text { High }\end{array}$ & $\begin{array}{l}1 \cdot 00 \\
2 \cdot 08(0 \cdot 94 \text { to } 4 \cdot 60) \\
2 \cdot 12(1 \cdot 11 \text { to } 4 \cdot 04)\end{array}$ \\
\hline
\end{tabular}

${ }^{\star}$ Reference value.

factors for insulin dependent diabetes and the MantelHaenszel risk estimates when protein was taken into account was $1.43(p=0.05)$ for medium exposure and $1.53(\mathrm{p}=0.04)$ for high exposure. The MantelHaenszel extension test was still significant $(p=0 \cdot 03)$.

The trend of odds ratios for carbohydrates was significant but non-linear. Monosaccharides and disaccharides, which are often tied with carbohydrates, were analysed stratified according to level of intake of foods rich in carbohydrates. The Mantel-Haenszel risk ratio then fell to $1.03(p=0 \cdot 87)$ and $1 \cdot 18(p=0 \cdot 66)$ for medium and high levels of intake of monosaccharides and disaccharides respectively. Thus carbohydrates but not monosaccharides or disaccharides may be risk factors for insulin dependent diabetes.

A similar analysis was performed for vitamin $C$, the effect of which could be confounded by the effect of vegetables rich in nitrates or nitrites. The effect of vitamin C totally disappeared when stratified for nitrates or nitrites giving a Mantel-Haenszel risk estimate for medium intake of $0.74(p=0.12)$ and for high intake of $1.04(p=0.86)$. In contrast, when intake of nitrates or nitrites was stratified for vitamin $\mathrm{C}$ the Mantel-Haenszel risk estimate was 0.94 for medium intake of nitrates or nitrites and $2.44(p<0.001)$ for high intake. The Mantel-Haenszel extension test showed a significant trend for intake of nitrates or nitrites, but the trend was not linear. Thus foods rich in nitrates or nitrites may be a risk factor for diabetes but those rich in vitamin $C$ are not.

Table $\mathrm{V}$ shows the trends and the standardised odds ratios for insulin dependent diabetes according to the frequency of intake of nutrient and additive risk factors. Standardising the odds ratio for potential confounders had little influence on the odds ratios or trends. Furthermore, no correlations were found between frequency of intake of different nutrients and indices of social class such as occupational or educational state of the parents.

\section{Discussion}

The study shows that a high frequency of intake of solid foods rich in protein or carbohydrate, or foods containing nitrosamine compounds may increase the risk for insulin dependent diabetes in humans. Since streptozocin was shown to induce diabetes in experimental animals ${ }^{28}$ it has been clear that toxic agents, possibly introduced by food, might cause the destruction of B cells. Streptozocin is chemically related to the nitrosamines and other similar compounds may occur in food products or be synthesised in the stomach from nitrates or nitrites..$^{21}$ Our observation that there was a dose response relation between frequency of intake of foods containing nitrosamine and the risk of children developing insulin dependent diabetes seems to con-

TABLE V-Odds ratios for risk of developing diabetes in childhood according to frequency of intake of various nutrients and food additives and standardised for potential confounders

\begin{tabular}{|c|c|c|c|c|c|c|c|c|c|c|c|c|}
\hline \multirow[b]{2}{*}{ Odds ratio } & \multicolumn{3}{|c|}{ Protein } & \multicolumn{3}{|c|}{ Carbohydrate } & \multicolumn{3}{|c|}{ Nitrosamines } & \multicolumn{3}{|c|}{ Nitrates or nitrites } \\
\hline & Low & Medium & High & Low & Medium & High & Low & Medium & High & Low & Medium & High \\
\hline Crude & $1 \cdot 0$ & $2 \cdot 34$ & $5 \cdot 49$ & $1 \cdot 0$ & $1 \cdot 33$ & $4 \cdot 35$ & $1 \cdot 0$ & $1 \cdot 73$ & $2 \cdot 56$ & $1 \cdot 0$ & $0 \cdot 84$ & $2 \cdot 41$ \\
\hline \multicolumn{13}{|l|}{ Standardised for: } \\
\hline Age & $1 \cdot 0$ & $2 \cdot 42$ & $5 \cdot 44$ & 1.0 & $1 \cdot 37$ & $4 \cdot 28$ & $1 \cdot 0$ & 1.93 & $2 \cdot 56$ & $1 \cdot 0$ & 0.85 & $2 \cdot 37$ \\
\hline Sex & $1 \cdot 0$ & $2 \cdot 32$ & $5 \cdot 51$ & $1 \cdot 0$ & 1.32 & $4 \cdot 71$ & $1 \cdot 0$ & 1.73 & $2 \cdot 58$ & $1 \cdot 0$ & 0.84 & $2 \cdot 45$ \\
\hline Maternal age & $1 \cdot 0$ & $2 \cdot 19$ & 4.98 & $1 \cdot 0$ & 1.48 & $4 \cdot 37$ & $1 \cdot 0$ & 1.75 & $2 \cdot 47$ & $1 \cdot 0$ & $0 \cdot 77$ & $2 \cdot 36$ \\
\hline Maternal education & $1 \cdot 0$ & $2 \cdot 39$ & $5 \cdot 63$ & $1 \cdot 0$ & $1 \cdot 37$ & $4 \cdot 58$ & $1 \cdot 0$ & 1.86 & $2 \cdot 58$ & $1 \cdot 0$ & 0.88 & $2 \cdot 88$ \\
\hline $\begin{array}{l}\text { Family history of insulin dependent } \\
\text { diabetes }\end{array}$ & $1 \cdot 0$ & $2 \cdot 73$ & $5 \cdot 42$ & $1 \cdot 0$ & $1 \cdot 46$ & $4 \cdot 32$ & $1 \cdot 0$ & $1 \cdot 70$ & 2.57 & $1 \cdot 0$ & 0.89 & $2 \cdot 68$ \\
\hline
\end{tabular}


firm that frequent and perhaps long term exposure to these compounds is also toxic to the human $\mathrm{B}$ cell. The trend for foods rich in nitrates or nitrites was more difficult to interpret.

During the past few years proteins and certain amino acids have been suggested to be triggers of insulin dependent diabetes in the BB rat. "' Our finding of a dose response relation between the risk for insulin dependent diabetes in childhood and frequency of intake of nutrients rich in protein is therefore of interest. Protein from cows' milk may trigger the autoimmune response that destroys $\mathrm{B}$ cells in laboratory rats, and as children who develop diabetes are often breast fed for a shorter period ${ }^{512}$ it has been suggested that proteins in cows' milk are also risk factors for human diabetes. ${ }^{29}$ Our separate analysis for milk and milk combined with milk products showed no clear indication that milk is a risk factor for insulin dependent diabetes; rather a tendency to a decreased risk was noted. As Swedish children drink milk very frequently a much larger study might be necessary to clarify any possible effect of milk proteins.

A high frequency of intake of foods rich in carbohydrate also seemed to increase the risk for insulin dependent diabetes in our study; the dose response curve was non-linear, implying a threshold effect. Many of the foods rich in carbohydrate are also rich in wheat gliadin. Our findings could therefore support the hypothesis that gliadin proteins might be harmful to the $\mathrm{B}$ cell, at least in $\mathrm{BB}$ rats..$^{29}$ Alternatively, a frequent intake of food rich in carbohydrate might well be considered as a stress for the B cell and fits well with the hypothesis that B cells stimulated by glucose are more susceptible to cytotoxic action of interleukin 1 or tumour necrosis factor in experimental models. ${ }^{3 \prime}$ This is also in accordance with our findings of a higher frequency of snacks among diabetic than among control children.

As in all case-control studies many sources of errors must be considered. Firstly, the number of nonresponders in our study was higher among controls than among diabetic children; secondly although we found no specific selection with regard to age, sex, and county of residence among the non-responders, a higher proportion of non-responders could have been in the lowest and highest social classes. ${ }^{31}$ Maternal education, however, an important determinant for social class, had no effect on the significant trends for any of the nutritional risk factors for insulin dependent diabetes. Furthermore, a hypothetical calculation adjusting for the difference in the number of nonresponders in the two groups showed that the odds ratio for high frequency of intake of protein would become insignificant only if more than $92 \%$ of nonresponding controls had a protein intake exceeding the 75 th centile of frequency, as calculated from the results of all participating responders.

An incorrect classification or missed case of insulin dependent diabetes is unlikely to have occurred in this study, as the study base was ascertained through the Swedish childhood diabetes registry, which covers more than $99 \%$ of all cases in children aged $0-15 .^{2}$ The possibility of incorrect recording of frequency of consumption of nutrients is much larger. This type of questionnaire on food frequency has been widely used in other studies because it is cost effective, but it will give only qualitative and not quantitative information on intake of different foods. The questionnaire that we used has been evaluated in a group of healthy and diabetic children and compared with seven day prospective food records. No systematic differences were found between diabetic and non-diabetic children, although the evaluation showed that the questionnaire had a rather low sensitivity $(0 \cdot 4-0 \cdot 5)$ but a high specificity $(0 \cdot 9-1 \cdot 0)$ compared with the seven day prospective food diary. ${ }^{1 \times}$ The specificity and sensitivity in this context defines the ability of the questionnaire to identify correctly high and low consumers of a specific nutrient. Nevertheless, the decrease in sensitivity as well as that in specificity was independent of disease and thus the questionnaire would underestimate relative risks.

The most serious problem in a case-control study of this kind is the possibility of biased misrecording of food intake: parents of children who had developed diabetes had all recently received dietary information from the hospital dietitian, and this information might have affected their responses despite their being told to report on eating habits before any possible change in diets. Again, results from a previous study would suggest that such misrecording does not occur. ${ }^{1 \times}$ Our results did not show any systematic trend-for example, parents of diabetic children did not report either an idealised or a contrasting diet compared with that recommended for diabetes. Thus diabetic children were reported to have a high frequency of consumption of monosaccharides or disaccharides and fat as well as fibre and vitamin C. Further, the diabetic children or their parents were unlikely to have been aware that foods containing high amounts of nitrosamine, nitrates or nitrites, or protein were associated with insulin dependent diabetes. Nevertheless, the results should be considered with great caution and only a large prospective study, which would be extremely expensive in terms of time and money, can finally confirm these results.

The study was supported by grants from the Swedish Medical Research Council (Project number 07531), the Karolinska Institute, the Nordic Insulin Foundation, the Swedish Diabetes Association, Svenska Diabetesstiftelsen, NOVO company, and Förenade LIV (Mutual Life Assurance Company)

1 Dahlquist (G, Blom L, Holmgren G, et al. The epidemiology of diabetes in Swedish children 0-14 years - a six-year prospective study. Diabetologia 1985;28:802-8

2 Nyström L, Dahlquist G, Rewers M, Walt S. The Swedish childhood diabetes studv - an analysis of the temporal variation in diabetes incidence 1978-1987. Int f Eidemiol 1990;19:141-6.

3 Reunanen A, Äkerblom HK, Käär ML. Prevalence and ten-year (1969-1979) incidence of insulin-dependent diabetes mellitus in children and adolescents in Finland. Acta Paediatr Scand 1982;71:893-9.

4 Joner (G, Sovik (). Incidence, age at onset and seasonal variation of diabetes mellitus in children and adolescents in Norwegian children 1973-1977. Acta Paediatr Scand 1981;70:329-35.

5 Patterson CC, Thorogeod M, Smith PG, Heasman MA, Clarke JA, Mann JI. Epidemiology of type I (insulin-dependent) diabetes in Scotland 1968-1976: evidence of an increasing incidence. Diabetologia 1983; 24: $238-43$

6 North AF, Gorwizy K, Sulzz HA. A secular increase in the incidence of juvenile diabetes mellitus. F Pediatr 1977;91:706-10.

Stewart BS, Haslum M, Butler $N$. Evidence for increasing prevalence of diabetes mellitus in childhood Br Med f 1983;286:1855-7.

8 diabetes mellitus in childhood Br Med f 1983;286: 1855-7.

9 Blom L. Dahlyuist (i, Nystrom L, Sandstrom A, Wall S. The Swedish childhoxd diabetes study - social and perinatal determinants for diabetes in childhood diabetes study - social and

childhood. Diabetologia 1989:32:7-13.
Hagman U, Bruce Ä, Persson LA, Samuelsson G, Sjölin S. Forod hahits and nutrient intake in childhood in relation to health and socio-economic conditions. A Swedish multicenter study 1980-81. Acta Paediatr Scand 1986(suppl);328:5-56.

11 Scott FW, Mongeau R, Kardish M, Hatina (i, Trick KD), Wojcinski \%. Dict can prevent diabetes in the BB rat? Diabetes 1985;34:1059-62.

12 Elliot RB, Martin JM. Dietary protein: a trigger of insulin-dependent diabetes in the BB rat? Diabetologia 1984;26:297-9.

13 Helgason T, Jonasson MR. Evidence for a foed additive as cause of ketosisprone diabetes. Lancet 1981;ii:716-20.

14 Helgason T, Ewen SW, Ross IS, Stowers JM. Diabetes preduced in mice by smoked/cured mutton. Lancet 1982;ii: 1017-22.

15 Wilander $\mathrm{E}$, Gunnarsson R. Diabetogenic effects of the $\mathrm{N}$-nitrosomethylurea in the Chinese hamster. Acta Pathol Microhiol Immunol Scand /A/ 1975;83: in the $C$.

16 Dahlquist (i, Blom L., Tuvemo T, Nyström L, Sandstrom A, Wall S. The Swedish childhood diabetes study - results from a nine year case register study and a case-referent study indicating that IDIDM is associated with both NIDDM and autoimmune disorders. Diabelologia 1989;32:2-6.

17 Holm A-K, Blomquist H, K: son-Crossner C-C;, Grahnén H, Samuelsson (j. A comparative study of oral health as related to general health. Fexd habits as secio-economic conditions of 4-year-old Swedish children. Community Dental and ()ral Lipidemiologv 1975;3:34-9.

18 Blom L, Lundmark K, Dahlquist (i, Persson I-A. Estimating children's eating habits-validity of a questionnaire measuring ferd frequency compared to a 7-day-record. Actu P'aediatr Sicand 1989;78:858-64.

19 Swedish National Foed Administration. Food composition tables 1988. Uppsala: Statens 1.ivsmedelswerks Förlag, 1988. 
20 Swedish National Food Administration. Swedish Food Regulations. Food additives. Uppsala: Swedish National Food Administration, 1985.

21 Fine DH, Ross R, Rounbehler DP, Silvergleid A, Song L. Formation in vivo of volatile $\mathrm{N}$-nitrosamines in man after ingestion of cooked bacon and spinach. Nuture 1977:265:753-5.

22 Osterdahl BG. Volatile nitrosamines in foods on the Swedish market and estimation of their daily intake. Food Addit Contam 1988:5:587-95.

23 Wagner DA, Shuker DEG, Bilmazes $C$, et al. Effect of vitamin $C$ and $b$ on endogenous synthesis of $\mathrm{N}$-nitrosamino-acids in humans: precursorproduct studies with ("N) nitrate. Cancer Res 1985;45:6519-22.

24 Jenkins DJA, Wolever TMS, Jenkins AL, Taylor RH. Dietary fibre, carbohydrate metabolism and diabetes. Mol Aspects Med 1987;9:97-112.

25 Miettinen O. Components of the crude risk ratio. Am 7 Epidemiol 1972:96: $168-72$.

26 Klecka WR. Discriminant analysis. In: Nie NH, Hull $\mathrm{CH}$, Jenkins JG,
Steinbrenner K, Bent DH, eds. Statistical package for the social sciences. 2nd ed. New York: Mc(iraw-Hill, 1975:434-47.

27 Miettinen O. Estimability and estimation in casc-referent studies. $\mathrm{Am}$. Epidemiol 1976;103:226-35

28 Rakieten N, Rakieten ML, Nadkarni MV. Studies on the diahetogenic action of streptozotocin. Cancer Chemotherapy Reports 1963:29:91-8.

29 Scott FW, Daneman D, Martin JM. Evidence for a critical role of diet in the development of insulin-dependent diabetes mellitus. Disheres Res 1988:7: $153-7$.

Nerup J, Mandrup-Poulsen T, Molvig J, Helyvist S, W'ogensen L, Egeterg J. Mechanisms of pancreatic B-cell destruction in trpe 1 diabetes. Diahcles Ciare 1988:11:16-23.

31 Tibblin G. A population study of 50-year-old-men. An analysis of the nonparticipating group. Acta.Med Scand 1965;178:453-9.

(Accepted 6 March 1990)

\title{
Has the prevalence of asthma increased in children? Evidence from the national study of health and growth 1973-86
}

\author{
P G J Burney, S Chinn, R J Rona
}

\begin{abstract}
Objectives-To estimate changes in the prevalence of reported symptoms of respiratory disease and reported diagnoses of asthma and bronchitis in primary school children in England between 1973 and 1986.

Design-Mixed longitudinal survey.

Setting-Representative sample of English primary schools in 22 areas.

Participants-15000 Boys and 14156 girls each studied at least once between 1973 and 1986.

Data collected - Whether, according to the parent or guardian, the child had wheezed, wheezed on most days or nights, or had attacks of bronchitis or asthma in the past year.
\end{abstract}

Results - Within age groups trends in successive annual cohorts showed an increasing prevalence of asthma for each annual birth cohort (boys, 6.9\%, $\mathrm{p}<0.001$; girls, $12.8 \%, p<0.001$ ) and of wheeze on most days or nights (boys, $4.3 \%$ per cohort, $\mathrm{p}<0.001$; girls, $6.1 \%$ per cohort, $\mathrm{p}<0.001$ ) and a falling prevalence of bronchitis (boys, $-4.7 \%$ per cohort, $\mathrm{p}<0.001$; girls, $-5.8 \%$ per cohort, $\mathrm{p}<0.001$ ). There was a smaller increase in the prevalence of wheeze whether or not it occurred on most days or nights, and this increase was significant only among the girls (boys, $1.0 \%$ per cohort, $p>0.05$; girls, $1.7 \%$ per cohort, $p<0 \cdot 05$ ). Although the rate of increase of "asthma" was greater than the rate of decrease in "bronchitis," the baseline prevalence of asthma was much lower than that of bronchitis, and the total proportion of children with either diagnosis declined slightly over the whole period. The main change was an increase in the proportion of children whose parents stated that they had persistent wheeze and yet did not have a report of either "asthma" or "bronchitis."

Conclusions - These results suggest that there has been a true increase in morbidity that is not simply due to changes in diagnostic fashion. The increase is large enough to explain much if not all of the increase in admission to hospital and mortality, and it underlines the importance of an understanding of the aetiology of asthma in tackling the causes of the recent increase.

\section{Introduction}

Mortality from asthma among 5-34 year olds increased between the mid-1970s and the mid-1980s.' This increase was the more surprising as mortality had been falling in most conditions for which there was effective prevention or treatment. ${ }^{2}$ At the same time more children with asthma had been admitted to hospital ${ }^{34}$ and consultations with general practitioners for asthma virtually doubled between 1970-1 and 1981-2.5

Each of these changes could be due to a change in medical practice, including a change in the use of diagnostic labels, or to a change in the prevalence of the disease. There is some indirect evidence that the prevalence of asthma may have been increasing, but other evidence suggests that there has been no change. Smith found an increase in the prevalence of asthma in Birmingham in the $1960 \mathrm{~s},{ }^{6}$ but this evidence was collected at a time of great demographic change when the city was being largely rebuilt. Wadsworth compared those who had been studied in the 1946 national perinatal survey with their firstborn offspring and showed that the children had a threefold greater chance of having been treated for asthma before their fifth birthday, ${ }^{7}$ but this could have been explained by differences in management or differences in diagnostic practice. Hill et al estimated that the prevalence of wheeze in Nottingham schoolchildren increased $1-28 \%$ between 1985 and 1988 and suggested that the large increase in estimated "asthma" was due to a change in diagnostic labelling. ${ }^{8}$ More recently Burr et al showed increases between 1973 and 1988 in both symptoms and bronchial response to exercise in 12 year old children attending schools in Caerphilly. ${ }^{9}$

On the other hand, Hay and Higginbottam, Anderson, and Hill $e t$ al have all pointed to the lack of any trend over time in the results from published surveys reporting the prevalence of asthma. ${ }^{10-12}$ As Anderson points out, however, the interpretation of this evidence is difficult because the methods used in each survey are different and estimates of the prevalence of asthma are likely to be sensitive to these differences. ${ }^{13}$ Geographical variation in the prevalence of asthma would also confound any estimate of trend from these data.

Indications that asthma may be an increasing problem are not confined to the United Kingdom Upward trends in mortality have also been noted in New Zealand, France, Germany; Denmark, and possibly the United States. ${ }^{1+16}$ Upward trends in hospital admissions have also been noted in New Zealand and the United States. ${ }^{17} 18$

This paper reports trends in the prevalence of respiratory conditions, including both diagnoses and symptoms, reported by the parents and guardians of children in the national study of health and growth between 1973 and 1986. Estimates of the trends in prevalence have been made for cohorts of children living in England and born between 1961 and 1981. 